\title{
Stress Testing of Banking Systems: an examination against the Shocks of Macroeconomic Variables
}

\section{Pruebas de estrés de los sistemas bancarios: un examen contra los choques de las variables macroeconómicas}

\author{
Kamiar Askari (D) \\ Ph.D. candidate for Financial Management, Faculty of Economics and Accounting, South \\ Tehran Branch, Islamic Azad University, Tehran, Iran \\ ORCID: https://orcid.org/0000-0003-1851-3851

\section{Fatemeh Sarraf} \\ Assistant Professor of Economics and Accounting Faculty, South Tehran Branch, Islamic Azad \\ University, Tehran, Iran \\ ORCID: https://orcid.org/0000-0002-9953-4525

\section{Roya Darabi} \\ Assistant Professor of Economics and Accounting Faculty, South Tehran Branch, Islamic Azad \\ University, Tehran, Iran \\ ORCID: https://orcid.org/0000-0003-1385-1034
}

Fatemeh Zandi

Assistant Professor of Economics and Accounting Faculty, South Tehran Branch, Islamic Azad

University, Tehran, Iran

ORCID: https://orcid.org/0000-0002-4139-5948

Received 02-08-20 Revised 04-10-20

*Correspondence

Email: sarraf@aftermail.ir
Accepted 01-12-21 On line 01-18-21

Cite as:

Askari, K., Sarraf, F., Darabi, R. \&Zandi, F. (2021). Stress Testing of Banking Systems: an examination against the Shocks of Macroeconomic Variables. Propósitos y Representaciones, 9 (SPE1), e889. Doi: http://dx.doi.org/10.20511/pyr2021.v9nSPE1.889 


\section{Summary}

In the past years, overdue due receivables of the banks have increased in an unprecedented way compared to all the facilities granted in Iran's banking network, showing the not very acceptable quality of bank assets that decrease the bank credit and make them financially unstable. The macroeconomic variables in this article are as follow: GDP growth rate, economic growth, exchange rate, inflation rate, unemployment rate, government debt. The decrease in this amount of arrears shows the ability of banks to maintain their resources. At this research, after identifying the macroeconomic variables affecting the default of banks using the stress test and applying one standard deviation with the help of the historical scenario, the study examined the banks' resilience to the shocks of these variables from 2006 to 2019. The results indicated that the shock of the economic growth rate had the greatest effect. In other words, the decrease in the economic growth rate had the greatest effect on the increase of borrowers' default rates. In addition to this, shocks of economic growth and government debt have highly effect on the borrowers' default rates and inflation rate, unemployment rate, GDP growth rate and exchange rate have a significant impact upon borrowers' default rates.

Keywords: Resilience, macroeconomic variables, stress test, historical scenario, banking system

\section{Resumen}

En los últimos años, las cuentas por cobrar vencidas de los bancos han aumentado de una manera sin precedentes en comparación con todas las facilidades otorgadas en la red bancaria de Irán, lo que demuestra la calidad no muy aceptable de los activos bancarios que disminuyen el crédito bancario y los vuelven financieramente inestables. Las variables macroeconómicas de este artículo son las siguientes: tasa de crecimiento del PIB, crecimiento económico, tipo de cambio, tasa de inflación, tasa de desempleo, deuda pública. La disminución de esta cantidad de atrasos muestra la capacidad de los bancos para mantener sus recursos. En esta investigación, luego de identificar las variables macroeconómicas que afectan el incumplimiento de los bancos mediante la prueba de estrés y aplicar una desviación estándar con la ayuda del escenario histórico, el estudio examinó la resistencia de los bancos a los choques de estas variables de 2006 a 2019. Los resultados indicaron que el impacto de la tasa de crecimiento económico tuvo el mayor efecto. En otras palabras, la disminución de la tasa de crecimiento económico tuvo el mayor efecto en el aumento de las tasas de incumplimiento de los prestatarios. Además de esto, los choques del crecimiento económico y la deuda pública tienen un gran efecto en las tasas de incumplimiento de los prestatarios y la tasa de inflación, la tasa de desempleo, la tasa de crecimiento del PIB y el tipo de cambio tienen un impacto significativo en las tasas de incumplimiento de los prestatarios.

Palabras clave: resiliencia, variables macroeconómicas, prueba de estrés, escenario histórico, sistema bancario.

\section{Introduction}

Financial crises can be the consequence of the deficiencies in the financial system and can be exacerbated by the same deficiencies. One of the factors that intensify the financial crises is the possibility of these crises spreading from one market to another. In Iran's financial markets, there is a crisis of transferring financial fluctuations from one market to another, where the necessity of using risk management methods from a micro and macro perspective to prevent or minimize the effects of financial crises makes is felt. Like any other business, banks and 
financial institutions are at risk too. The nature of financial activities and dealing with concepts like credit, payment systems, and different rates expose these institutions to special risks (Wei \& Yang, 2012). The rapid development of financial activities, technical innovations and the increase in the complexity of financial systems, on the other hand, has made risk management principles an inevitable part of any financial institution. Stability does not occur in the growth of financial institutions unless they are subject to rational and scientific risk management. In modern science, risk management has been discussed from a macro perspective (Cornett et al, 2018). This means that to the regulatory bodies in the financial field, especially central banks, risk management is an effective tool to maintain the growth of banking institutions. Predicting the probability of default is one of the most basic and essential principles of risk management in banks and financial institutions, internationally known as credit risk management principles (Nikolaos and Papanikolaou, 2018).

Among the most significant tasks of banks is to manage credit risk, because people's deposits with banks are a risk-free asset and oblige the bank to pay its principal and interest at certain maturities. However, the loan the bank pays to the companies may not be repaid. Thus, credit risk evaluation is of particular significance (Kanas and Molyneux, 2017). The losses due to the possibility that the borrower or the contracting party will not be able or unwilling to repay the loan are called credit risk. From another perspective, credit risk is the probability of loss in a credit transaction. In his book "Risk Management," McGraw-Hill, quoting from Michel Crouhy, defines credit risk as follows: Non-payment risk happens following a change in the factors that shape the credit quality of an asset. According to the definition of Basel Committee on Banking Supervision (BCBS), credit risk in its simplest form is the probability that a borrower or partner does not fulfill its obligations under the agreed terms (Crouhy \& et al., 2000, 68).

The experimental literature increasingly researches the causes and outcomes of bank fragility in contemporary economies. Studies of the banking crisis show that it largely relied on experience gained from the crises of the nineteenth and early twentieth centuries. In particular, the subject of the studies was the study of the Great Depression, until numerous bank failures occurred around the world.

Drehmann (2005) conducted a market-based macro-stress test for credit risk in British banks. He used the Merton model to calculate the probability of default. In the first step, the distribution of probability of default (PD) over different time horizons was examined. The pattern observed in all simulation results shows that the distribution is neither symmetric nor linear. On all prediction horizons, the PD in the best macroeconomic conditions is closer to the middle of the PD than to the PD in the worst macroeconomic conditions. Additionally, the results show that time is an important element because PD is one year ahead of more than twice the PD of 6 months. PDs of the industry show similar characteristics, although asymmetry and nonlinearity are more pronounced for some industries. The study only examined the effect of systematic risk factors on losses and specific risk factors were not simulated. Thus, only expected losses are addressed and not the total losses. For instance, the results show that for a 99\% quantile, the expected losses is less than 20 percent of capital, given the worst macroeconomic conditions over the one-year horizon. The conclusion is that even in the worst macroeconomic conditions, the expected losses of banks are not high enough to lead to the bankruptcy of banks. Stress tests show that systematic factors have an asymmetric and nonlinear effect on credit risk and that these effects are more important for more unfavorable scenarios.

Allen et al. (2005) studied the effect of sharp fluctuations in the value of bank assets on capital adequacy and PD of Japanese banks. They used quantile regression to analyze Merton's structural credit model to evaluate these two variables over a 10 -year period including global financial crises. Using quantile regression, the study show how the market value of assets changes at different points as a result of the distance to default and PD for banks that depend on time and quantile. The required capital is calculated by calculating credit risk over a cycle or by using static models that calculate risk at a specific point in time.

Boss (2002) introduced a model for the Austrian Bank stress test. In his model, he used Credit Portfolio View (Wilson, 1997) for the macro stress test. In this study, it is not possible to model the probability of default for different industrial sectors due to the lack of access to data. Hence, total PD for all economic sectors is modeled as a function of macroeconomic variables. 
Virolainen (2004) used Wilson's model (1997) in the context of the stress test in 1986: 1-2003:2 section of Finnish corporations. He suggested a credit risk model using industry-specific default rates. Defective data has been used for six main industries: 1) agriculture, 2) manufacturing, 3) construction, 4) trade, hotels and restaurants, 5) transportation and communications, and 6) other industries. The default rates were modeled using the logistic function and seemingly unrelated regression equations (SURE) model was used to determine the effect of macroeconomic variables on the default rates. The variables with the best explanatory power are GDP growth rate, debt ratio, and interest rates.

Wong et al. (2008) used the credit risk macro-stress test at Hong Kong banks to evaluate the risk of loan portfolio of banks and mortgage loan exposures. This test was based on the Wilson model (1997) and seasonal data from 1994 to 2006. In the model used, the default rate of each sector is considered as a function of macro variables, and an economic sector $\mathrm{J}$ to which banks lend is assumed. In this context, the stress test is performed by comparing the estimated cycles or distributing the probability of credit losses of the stress scenario with the distribution of the probability of credit losses of the baseline scenario. There are no artificial shocks in building the baseline scenario.

The model estimated for the Hong Kong Bank indicates a significant relationship between the bank loan default rate and macro variables. The results show that if the growth of GDP and asset prices decreases and interest rates increase, the default rate will be higher. The default rate coefficient with $\mathrm{Y}_{\mathrm{t}-2}$ interval is positive and significant. Thus, there is a positive autocorrelation in default rates, showing that macroeconomic shock can have a long-term effect on the default rate.

Wei \& Yang (2012) applied the stress test approach of Wong et al. (2008) to the Chinese banking industry. In this paper, the stress test is based on four variables: GDP growth rate, consumer price index, nominal money growth rate, and housing price index as macroeconomic variables and non-performing loans as a proxy for credit risk. VAR model is then used to examine the relationship between variables.

Cornett et al (2018) examined the bank behavior around Federal Reserve Stress Tests. They find that stress test banks increase capital ratios at the starting point for annual stress testing significantly more than non-stress test banks. Further, the differences between stress test and non-stress test banks seen in stress test years do not occur in 2010, when the Fed did not conduct a stress test. Results show that, as they enter the stress test, stress test banks lower dividends significantly more than non-stress test banks.

Kanas and Molyneux (2017) extended previous methodologies on macro stress testing by considering an additive semi-parametric quantile analysis which does not suffer from various specification problems and linearity limitations associated with standard approaches. The results are robust to alternative macro indicators and other measures of banking sector health.

Nikolaos and Papanikolaou (2018) developed a model that estimates the joint determination of the probability of a distressed bank to go bankrupt or to be bailed out. They obtained precise parameter estimates and superior in- and out-of-sample forecasts, which demonstrate that the determinants of failures differ from those of bailouts. Overall, they provide a concrete and reliable mechanism for preventing welfare losses due to bank distress.

According to the problems stated, one can state that in case of non-repayment of the granted facilities, the banks face many problems. Thus, there is a need to identify the major factors that affect borrowers and examine the effect of each on these borrowers to determine which variable affects more and how much changes in these variables affect borrowers' ability to repay loans. Besides examining these variables, the banks must estimate the precautionary capital needed to deal with non-repayment of loans to use this precautionary capital as a protective shield to protect themselves from the risks during the default period.

The structure of the study is such that after reviewing the experimental studies done in this field, we will explain the variables and the research method. We will estimate the model and analyze it, apply the shock of a standard deviation to the probability of failure, and in the end, we will conclude and make suggestions based on the purpose of the study according to the historical scenario. 


\section{Methodology}

As the study examined the resilience of banks against macroeconomic shocks, the population was all banks across the country, and the required quarterly information was obtained from the Central Bank from 2006 to the fourth quarter of 2019. Scenario building based on the stress of one standard deviation and historical data were used. In this study, Probability of Default (PD) rate is considered only a function of macroeconomic variables.

The first step in evaluating credit risk exposure and the potential losses that financial institutions face is to estimate PD. PDs are used as a primary tool in systematic risk evaluation as well, and stress testing of financial systems. Thus, credit risk predictions are very important to financial and monetary industry actors as well as legislators, especially under the new Capital Adequacy Framework (BCBS 2), and encourage banks to measure PD. PDs must first be modeled to perform a credit risk stress test. Estimating the probability of default due to the limitations of available data can be a major challenge, but many models have overcome these limitations.

This study will be based on Wilson's model. In the Wilson's model, first, the default rate is converted to a macroeconomic index using the logistic function. Then the effects of macroeconomic variables on it are estimated through a linear regression equation. If the variable resulting from the logistic conversion of the default rate has a single root and is not stationary, it will follow the approach of Boss (2002) and the annual change of this variable will be regressed on the explanatory variables. Moreover, in this dissertation, the VAR model is used to study the relationships between macroeconomic variables instead of AR to consider the interactions between macroeconomic variables. By applying the changes stated in the Wilson's model, the system of equations is presented as the following equations.

$$
\begin{aligned}
& p_{t}=\frac{1}{1+e^{-\left(y_{t-1}+\Delta y_{t}\right)}} \\
& y_{t-1}+\Delta y_{t}=\ln \left(\frac{p_{t}}{1-p_{t}}\right) \\
& \text { Formula } 1 \\
& \text { Formula } 2 \\
& \Delta y_{t}=\beta_{0}+\beta_{1} x_{1, t}+\beta_{2} x_{2, t}+\ldots+\beta_{k} x_{k, t}+\varepsilon_{t} \quad \text { Formula } 3 \\
& X_{t}=\gamma_{0}+\sum_{j=1}^{q} \gamma_{j} X_{t-j}+v_{t} \\
& E=\left[\begin{array}{l}
\varepsilon_{t} \\
v_{t}
\end{array}\right] \approx N\left(0, \sum\right), \sum=\left(\begin{array}{cc}
\sum_{\varepsilon} & \sum_{\varepsilon, v} \\
\sum_{v, \varepsilon} & \sum_{v}
\end{array}\right]_{\text {Formula } 5}
\end{aligned}
$$

$\mathrm{P}_{\mathrm{t}}$ is $\mathrm{PD}$ and $\mathrm{y}_{\mathrm{t}}$ is the macroeconomic index at time $\mathrm{t}$. This index can show the general state of the economy, determined by the macroeconomic factors studied. $X_{t}$ is vector of $\mathrm{k}$ macroeconomic variable ${ }^{\left(x_{1, t}, \ldots, \mathrm{x}_{K, t}\right)}$.

Macroeconomic variables in this study are GDP growth, unemployment rate, inflation, growth of government debt to banks, exchange rate and economic growth rate.

Scenario selection in stress test is of the most significant dimensions of this test, which should examine the limit events. Macro scenarios were examined in the fourth quarter of 2019, and accordingly the results are calculated for a one-year time horizon the first quarter of 2020 to the fourth quarter of 2020. Scenarios can be both hypothetical and historical. In this dissertation, the scenarios were examined based on historical data because they have a high probability of occurrence due to their occurrence.

\section{Results}

\section{Model estimation and its analysis}

The ratio of non-current facilities to total facilities was used as a proxy variable for default rates in the study. The chart below shows the time series of this important ratio from 2006 to 2019. 
According to the figure1, one can state that among the macroeconomic variables, the unemployment rate has been more stable, and other variables, especially the exchange rate, have fluctuated sharply.

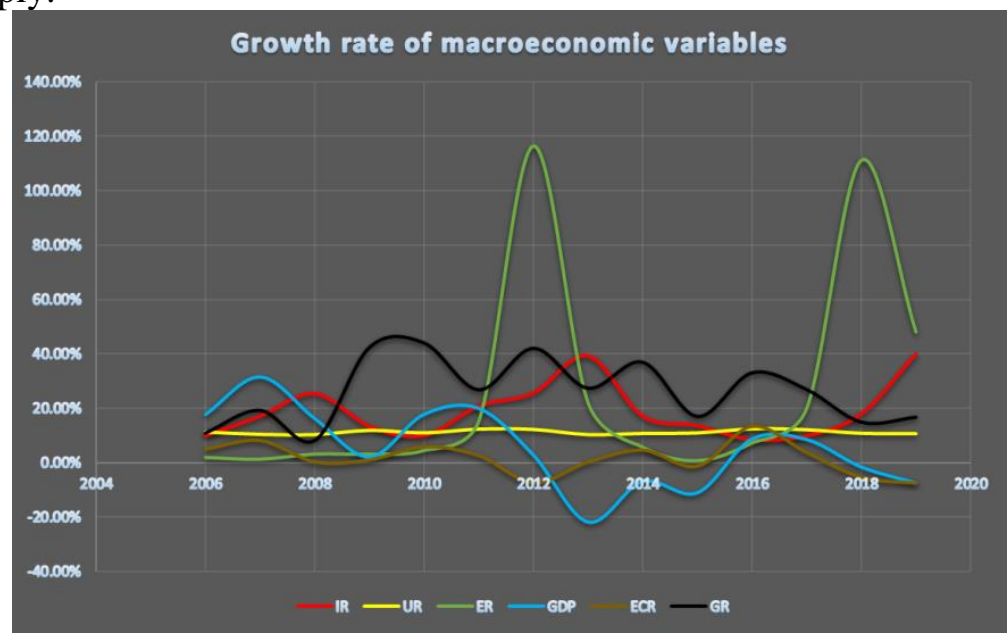

Figure1

Growth rate of macroeconomic variables in 2006 to 2019

The statistical characteristics of the variables from 2006 to 2019 are given in the figure 1 . In addition to this, table 1 is statistical properties of variables.

Table 1

Statistical properties of variables

\begin{tabular}{|c|c|c|c|c|c|}
\hline Maximum & Std. & Average & Minimum & Description & $\begin{array}{c}\text { Variable } \\
\text { Name }\end{array}$ \\
\hline 0.29 & 0.05 & 0.21 & 0.12 & PD & PD \\
\hline-1.24 & 0.25 & -1.59 & -2.12 & logistic function & Y \\
\hline 0.40 & 0.10 & 0.19 & 0.09 & $\begin{array}{c}\text { Percentage of } \\
\text { inflation rate }\end{array}$ & IR \\
\hline 0.12 & 0.01 & 0.11 & 0.10 & $\begin{array}{c}\text { Percentage of } \\
\text { unemployment rate }\end{array}$ & UR \\
\hline 1.16 & 0.38 & 0.26 & 0.01 & $\begin{array}{c}\text { Percentage of } \\
\text { exchange rate }\end{array}$ & ER \\
\hline 0.13 & 0.06 & 0.02 & -0.08 & $\begin{array}{c}\text { Percentage of } \\
\text { economic growth } \\
\text { rate }\end{array}$ & ECR \\
\hline 0.14 & 0.05 & -0.22 & $\begin{array}{c}\text { Percentage of GDP } \\
\text { growth rate }\end{array}$ & GDP \\
\hline & 0.14 & & & & \\
\hline
\end{tabular}




\begin{tabular}{|l|l|l|l|l|l|}
0.44 & 0.12 & 0.26 & 0.08 & $\begin{array}{c}\text { Percentage of } \\
\text { government debt } \\
\text { growth rate }\end{array}$ & GR \\
\hline
\end{tabular}

The shock applied to each variable is equal to one standard deviation, and the scenario of one standard deviation of the shock and the baseline scenario are both plotted on one axis to facilitate the task of impact analysis.

Economic growth and GDP growth were two macroeconomic variables where only negative shocks were effective in the country's economy. Thus, all shocks caused by these two variables were considered negative in the study, and positive shocks were applied for other variables.

Table 2

Is showing the stress test scenarios with a shock of a standard deviation.

\begin{tabular}{|c|c|c|c|c|c|c|}
\hline $\begin{array}{c}\text { UR } \\
\mathbf{\%}\end{array}$ & $\begin{array}{c}\text { IR } \\
\mathbf{\%}\end{array}$ & $\begin{array}{c}\text { GR } \\
\mathbf{\%}\end{array}$ & $\begin{array}{c}\text { GDPR } \\
\mathbf{\%}\end{array}$ & $\begin{array}{c}\text { ER } \\
\mathbf{\%}\end{array}$ & $\begin{array}{c}\text { ECR } \\
\mathbf{\%}\end{array}$ & $\begin{array}{c}\text { Macroeconomics } \\
\text { variable }\end{array}$ \\
\hline 10.70 & 40.00 & 5.78 & -7.60 & 14.00 & -7.59 & $\begin{array}{c}\text { Amount in 3rd } \\
\text { season }\end{array}$ \\
\hline 107.00 & 3.54 & 1.97 & 76.00 & 14.00 & 63.25 & $\begin{array}{c}\text { one standard } \\
\text { deviation }\end{array}$ \\
\hline 214.00 & 7.08 & 3.93 & 152.00 & 28.00 & 126.50 & $\begin{array}{c}\text { two standard } \\
\text { deviation }\end{array}$ \\
\hline 321.00 & 10.62 & 5.90 & 228.00 & 42.00 & 189.75 & $\begin{array}{c}\text { three standard } \\
\text { deviation }\end{array}$ \\
\hline
\end{tabular}

Table2- the stress test scenarios with a shock of a standard deviation

Figure2 is Kernel density graph (we just show Kernel density for the unemployment rate). Kernel density of the default rate for the unemployment rate is with a shock of a standard deviation, and Figure 3 is a function of the cumulative distribution based on the shock of a standard deviation for a one-year time horizon $(h=4)^{1}$.

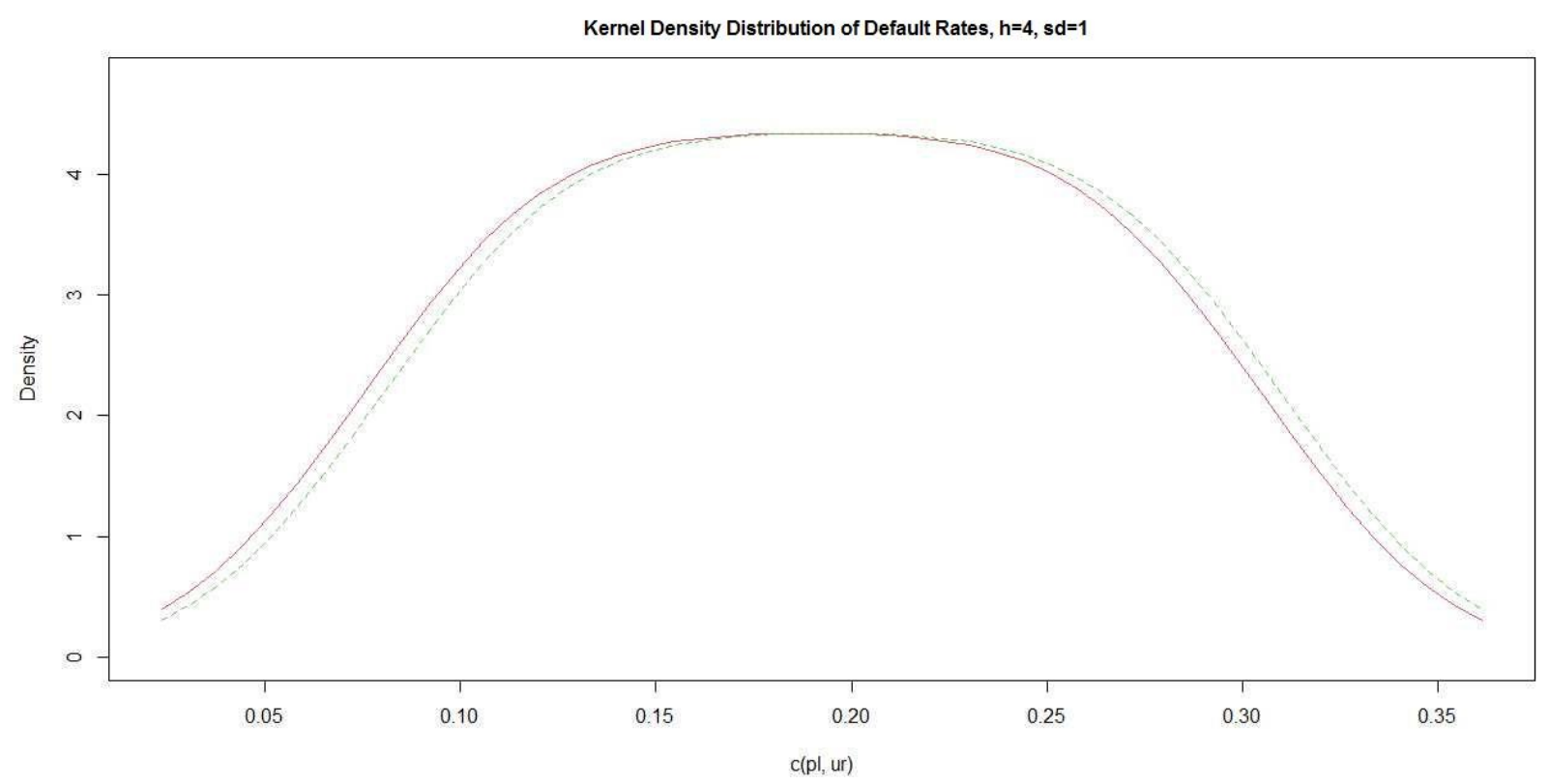

\footnotetext{
${ }^{1}$ The results of other shocks are attached 


\section{Figure 2}

Kernel density of the default rate for the unemployment rate with a shock of a standard deviation

As Figure 2 shows, with the increase in unemployment in the community, the income received by individuals naturally decreased, and this is the main reason for not repaying the facilities. Hence, the increase in unemployment leads to an increase in defaults, although this increase is insignificant.

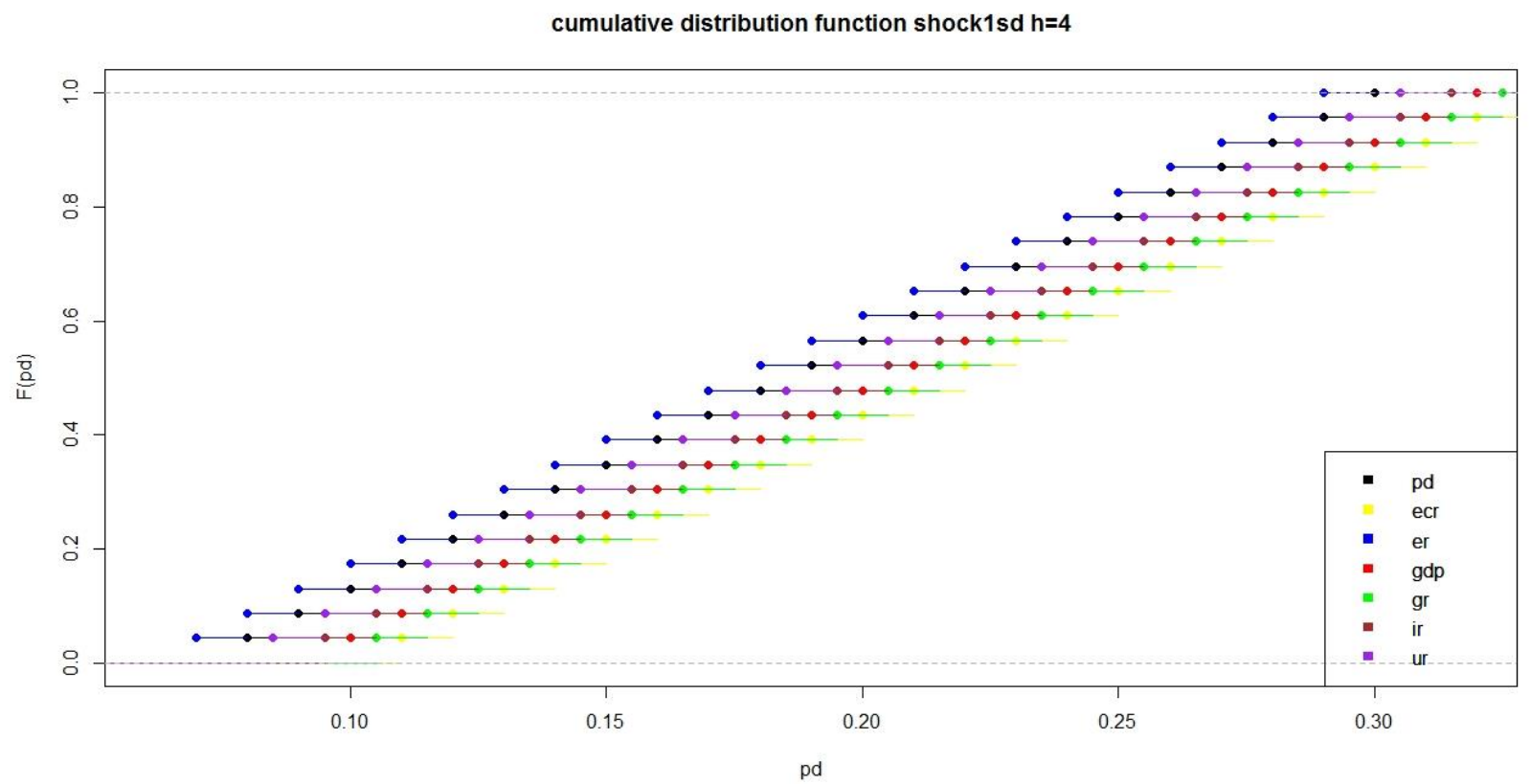

Figure 3

function of the cumulative distribution based on the shock of a standard deviation

Based on the results of figure 3, one can state that the unemployment rate has the least effect on the default rate, and the economic growth rate is the most effective shock due to the longest distance. According to this chart, all shocks affect the default rate. The only positive exchange rate shock is shifting the default rate distribution to the left. The increase in the exchange rate reduces the monetary value, which reduces imports and increases exports. The increase in exports seems to have a more positive effect on the decrease in imports and will lead to more currency appreciation.

Moreover, the devaluation of the monetary system may significantly reduce people's purchasing power, which will lead to an increase in their default. Additionally, increasing exports will increase the government's foreign exchange earnings and consequently reduce default. In general, considering the transfer of the default rate distribution to the left, one can conclude that an increase in the exchange rate reduces the default.

Then several stress scenarios based on historical data were presented. We turn the following selected scenarios into limit scenarios for Iran with the help of Monte Carlo simulation and repeating the simulation operation ten thousand times.

$15 \%$ increases in exchange rate growth (based on 2011 data) is shown in 'er' chart.

$11.19 \%$ decrease in GDP growth rate (based on 2015 data) is shown in the 'gdp' chart.

$7.59 \%$ decrease in the economic growth rate (based on 2019 data) is shown in the 'ecr' chart.

$26.96 \%$ increase in government debt (based on 2017 data) is shown in gr chart.

$18 \%$ increase in inflation (based on 2018 data) is shown in 'ir' chart.

$10.8 \%$ increase in the unemployment rate (based on data from 2014) is shown in 'ur' chart.

Based on the above scenarios and with the help of Monte Carlo simulation, one can draw a 
graph of default rate changes based on each scenario as well as the cumulative distribution function to evaluate the effectiveness of each. For instance, Figure 3 shows Kernel distribution diagram of the default rate under the scenario of a $7.59 \%$ decrease in the economic growth rate ${ }^{2}$. According to the figure 4 and figure 5, one can state that with the impact of the economic growth rate scenario, the largest change in the default rate occurs, so that at a $75 \%$ confidence level, the default rate has increased from $22 \%$ to more than $25 \%$. The unemployment rate has the least impact on the default rate.

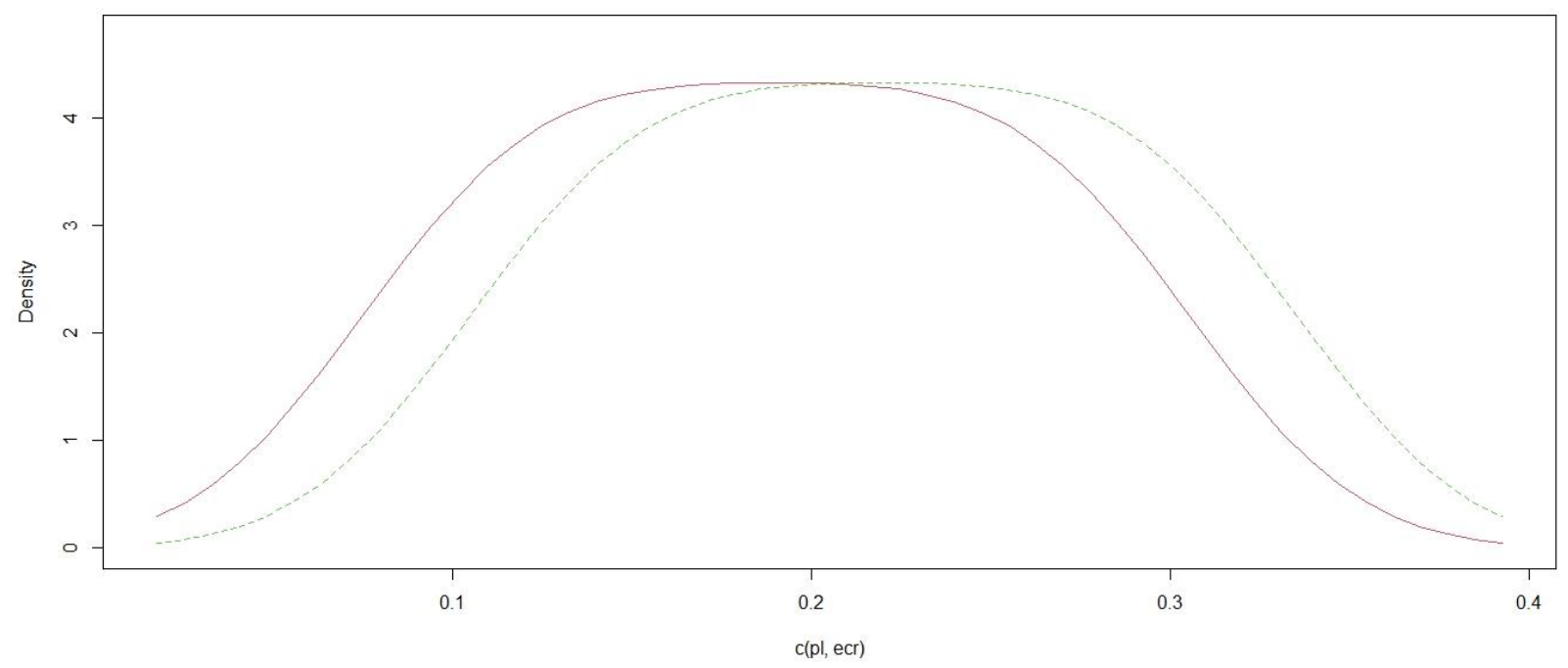

Figure 4

Kernel density of the default rate for the economic growth rate with $7.59 \%$ decrease

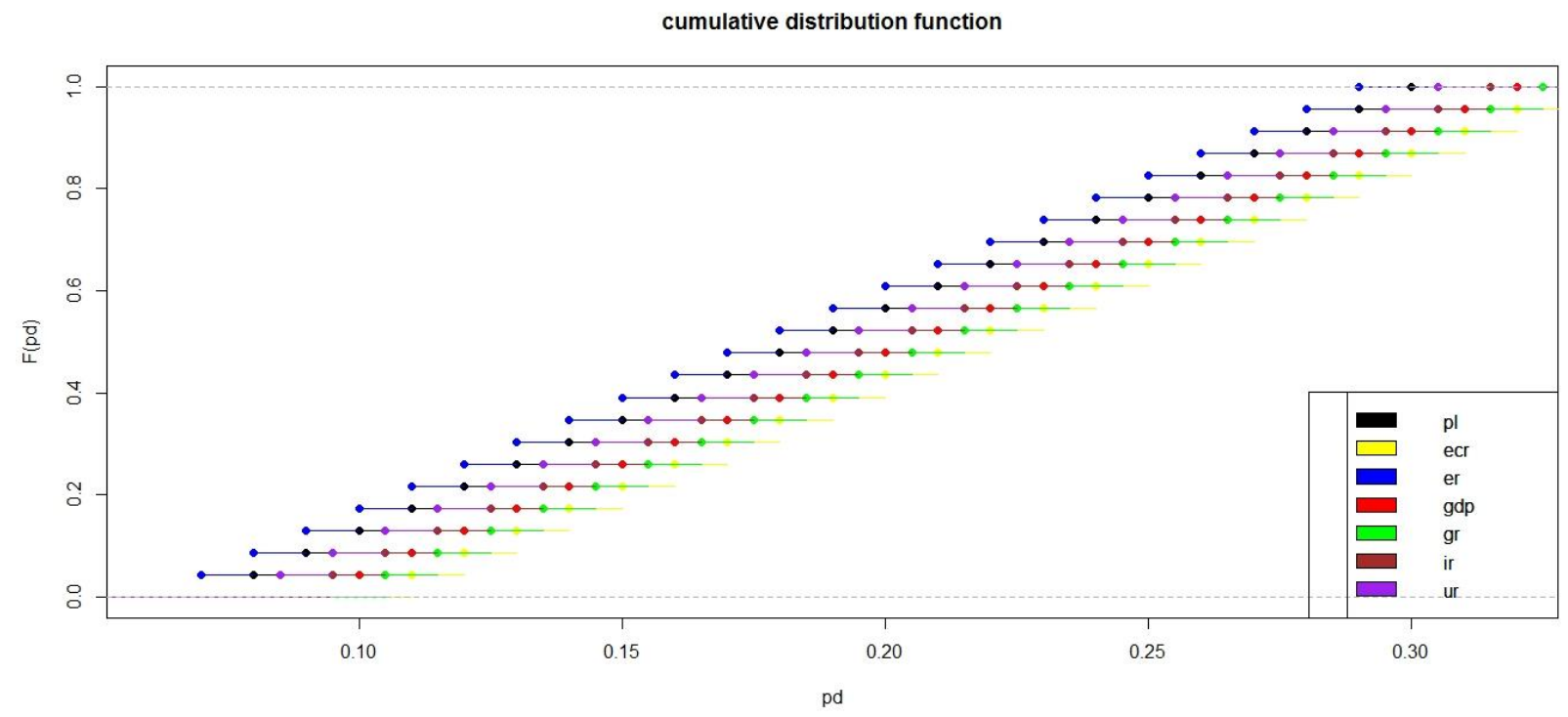

Figure 5

Function of the cumulative distribution based on the historical scenario

\section{Discussion}

According to the results, one can state that the economic growth rate has the greatest effect on PD. The government debt growth rate, GDP growth rate, inflation rate, and unemployment rate

\footnotetext{
${ }^{2}$ The results of other shocks are attached 
are in the next ranks, respectively, all of which are directly related to PD (economic growth shocks and GDP growth have been negatively applied) and only the exchange rate growth has an indirect relationship. This means that PD decreases as the exchange rate increases.

For instance, with a 7.59\% decrease in the economic growth rate (based on 2019 data), the default rate has increased from $22 \%$ to more than $25 \%$ at the $75 \%$ confidence level.

According to the results, a decrease in GDP growth rate means reducing the level of hope for profitable and economic activities, and borrowers will be less able to repay. Thus, a decrease in the GDP rate will lead to an increase in PD. As the rate of economic growth decreases, PD increases. As the rate of economic growth decreases, the level of confidence in investment decreases, and the income from it decreases, thus increasing the probability of default. Thus, the default rate distribution goes to the right. An increase in the exchange rate reduces the monetary value, reducing imports increasing exports. It seems that increasing exports will have a more positive effect on reducing imports and lead to more currency.

The managers have a key role in risk management process. They need to identify effective risks, develop valid and numerical indices to measure them, analyze those using methods like stress tests, and measure the adjusted return on capital risk. By doing this, all banks will be able to manage all their business processes based on the adjusted return on their economic capital and resources. As much as banks need to invest enough capital in hedging forward risks, they need to be sufficiently aware of the need to identify, measure, monitor, and control credit risk, and the best way to do this is through the principles and rules of BCBS. This can be used as a roadmap in credit risk.

Given the positive role of banks in Iran's economy, it is suggested that accurate and comprehensive planning should be done to perform stress tests. Stress tests could provide information to prevent the effects of severe events. Stress test enables banks to raise capital in the face of economic shocks and to withstand these shocks. Another important point is that banks should identify all areas where there is a possibility of credit risk exposure. Moreover, prior to adopting any care process, they should consider the results of the stress test as a roadmap. Another problem with banks' lending is that they do not adequately consider the effects of business cycles while granting the facility, where administering stress tests that consider the periodic effects of economic activities can lead to convincing and complete decisions.

In the study of resilience with the help of the stress test, data has a key role. Thus, the Statistics Center of Iran and the Central Bank are suggested to pay more attention to that shorter (monthly) periods lead to better results. The existence of data analysis and prediction units in the world's banks is an integral part, which is, unfortunately, one of the missing links of Iran's banks, which needs more attention than before.

As already stated, besides credit risk, there are other risks, and the other researchers can do similar studies in case they have access to this data.

After accessing the monthly data, the researchers can conduct a similar study and compare the results with those of this paper.

\section{Conclusion}

Additionally, the devaluation of the monetary system may significantly reduce the purchasing power of the people, and this will lead to an increase in their default. On the other hand, increasing exports will increase the government's foreign exchange earnings and consequently reduce default. Overall, considering the transfer of the default rate distribution to the left, one can conclude that in general, an increase in the exchange rate reduces the default. As inflation increases, the PD increases. The inflation rate can affect the default rate in several dimensions.

On the one hand, with the increase in inflation, the wealth of a group of people should increase, and therefore PD of these people decreases. On the other hand, increasing the inflation rate for most people reduces their purchasing power. It, therefore, increases PD, and increasing inflation and reducing the purchasing power and repayment of people more affect the default rate. Thus, the distribution of default rates moves to the right. With the increase in unemployment in the community, the income of people has decreases naturally, which is the main reason for not repaying the facilities. Thus, an increase in unemployment leads to an increase in default. 
Compared to other macroeconomic variables, the unemployment rate has the least effect on PD. When the government reduces its debt to banks, it reduces PD, and vice versa; when its debt increases, the default distribution function will go to the right. Therefore, an increase in government debt will increase PD.

\section{References}

Allen, D., Boffey, E., \& Powell., R. (2011). A Quantile Monte Carlo approach to measuring extreme credit risk, Working Paper Series, Edith Cowan University.

Boss, M. (2002). A Macroeconomic Credit Risk Model for Stress Testing the Austrian Credit Portfolio, Financial Stability Report 4, Oesterreichische National Bank.

Cornett, M.M., Minnick, K., Patrick, J., \&Hassan Tehranian, S. (2018). An Examination of Bank Behavior around Federal Reserve Stress Tests. Journal of Financial Intermediation, 23, 150-165. doi: 10.1016/j.jP.2018.05.001.

Crouhy, M., Galai, D., \& Mark, R. (2000). A Comparative Analysis of Current Credit Risk Models. Journal of Banking \& Finance, 24, 59-117.

Drehman, M. (2005). A Market Based Macro Stress Test for the Corporate Credit Exposure of UK Banks, London: bank of England, Available Via the internet: http://www.bis.org/bcbs/events/rtfo5 Drehman.pdf.

Kanas., P., \& Molyneux, P. (2017). Macro stress testing the U.S. banking system. Journal of International Financial Markets, Institutions \& Money, 78, 255-279. doi:https://doi.org/10.1016/j.intfin.2017.12.006.

Nikolaos, I., \& Papanikolaou, M. (2018). A dual early warning model of bank distress. Economics Letters, 162, 127-130.

Virolainen, K. (2004). Macro Stress Testing with a Macroeconomics Credit Risk Model for Finlalnd. Bank of Finlalnd Discussion Papers, 11, 167-189.

Wei, L., \& Zhiwei, Y. (2012). Stress Testing of Commercial Bank's Exposure to Credit Risk: A study based on write-off nonperforming loan. Asian Social aciense, 8(10), 78-99.

Wong, J., Ka-Fai, C., \& Tom, F. (2008). A Framework for Stress Testing Bank's Credit Risk. The Journal of Risk Model Validation, 2(1), 3-23. 